\title{
The Model of Disadvantages? \\ The Choice-of-Law Provisions of the Commonwealth of Independent States Model Civil Code and Their Impact on National Legislations
}

\author{
NURZHAN YESHNIYAZOV*
}

\begin{abstract}
The article describes the distinctive features and main disadvantages of the Commonwealth of Independent States Model Civil Code's provisions of general parts of private international law, which found reception in the national legislation of the member states. The Code was accepted as a model for codification by the majority of the CIS states. An analysis of the Code's provisions can help interpret the unclear national rules, will allow to predict courts' modus operandi in conflict-of-laws cases and can provide an opportunity to estimate further development prospects of private international law in the post-Soviet area.
\end{abstract}

Keywords: Commonwealth of Independent States; Model Civil Code; private international law; choice of law; codification; application of conflict rules; application of foreign law.

\section{INTRODUCTION}

Twenty-five years ago, the Commonwealth of Independent States was created from the ruins of the Soviet Union. Rejection of the socialistic basis demanded the adoption of a new legislative superstructure in the area of private law. The falling of the Iron Curtain and the new independent states' claims for integration into the world community required a completely new approach to private international law (PIL). The decades of self-isolation and command economy together with new states' lack of legislative experience were impeding the law-making process for years. In 1994-1996, the Interparliamentary Assembly of the Commonwealth adopted the Model Civil Code ${ }^{1}$ (MCC), with Section VII 'Private international law', designed to become a model for codification in the member states in order to provide consistency of the national laws.

Subsequently, Uzbekistan (1996), ${ }^{2}$ Kyrgyzstan, ${ }^{3}$ Armenia, ${ }^{4}$ Belarus (1998) ${ }^{5}$ and Kazakhstan (1999) ${ }^{6}$ practically copied the MCC provisions into their national Civil Codes with minimal amendments. Russia enacted the Third Part of its Civil Code containing the

\footnotetext{
* Senior Lecturer, Department of International Law, KazGUU University, Kazakhstan. E-mail: nurzhan.yeshniyazov@gmail.com

1 The First Part had been adopted on 29.10.1994, the Second on 13.05.1995, and the Third (relevant to this paper) on 17.02.1996. Model Civil Code of the Commonwealth of Independent States (2015) link 1.

2 Civil Code of the Republic of Uzbekistan. Second Part of 29.08.1996. Uzbek text (2016) link 2; Russian text (2016) link 3.

${ }^{3}$ Civil Code of the Kyrgyz Republic. Part II of 05.01.1998. Kyrgyz text (2016) link 4; Russian text (2016) link 5.

${ }^{4}$ Civil Code of the Republic of Armenia of 28.07.1998 (2011) link 6.

5 Civil Code of the Republic of Belarus of 07.12.1998 (2016) link 7.

${ }^{6}$ Civil Code of the Republic of Kazakhstan. Special Part of 01.07.1999. Kazakh text (2016) link 8; Russian text (2016) link 9.
} 
Section on PIL in $2001^{7}$ and then further amended it twice in 2006 and 2013 that allowed the correction of some of its defects. Tajikistan enacted the Third Part of its Civil Code in $2005^{8}$ and copied the contemporaneous Russian version without any amendments. Azerbaijan $(2000)^{9}$ and Ukraine $(2005)^{10}$ have both adopted separate statutes on PIL, but their provisions in general were based on the MCC rules. The Moldovan Civil Code ${ }^{11}$ was influenced by the MCC and also by the Romanian legislation. ${ }^{12}$ Lastly, Turkmenistan, famous for its autarchy, enacted a Civil Code based on the MCC, but ignored Section VII and has been existing without any general provisions on conflict of laws for a quarter of a century. The only CIS member to completely ignore the MCC was Georgia, ${ }^{13}$ which adopted a separate statute on the basis of the Introductory Act to the German Civil Code. ${ }^{14}$

This article analyzes the distinctive features and main disadvantages of the MCC provisions on PIL, which were adopted by the CIS countries' national law. The analysis of these provisions can help interpret certain unclear rules of the national legislations, will allow to predict courts' modus operandi in conflict-of-laws cases and can provide an opportunity to estimate development prospects in this field.

Interpretation of particular choice-of-law provisions usually does not cause serious difficulties, therefore, this article will only consider the provisions of the general part of PIL which 'can be taken out of brackets in analyzing rules and institutions which form the content of the separate themes of the special part' and 'are important for the code as a whole'. ${ }^{15}$

The translation of the MCC's and the other statutes' provisions from Russian, and other Slavic and Turkic languages into English is performed by the author in an attempt to keep the incoherent style of the original texts.

\section{HISTORICAL BACKGROUND}

The pre-revolutionary Russian legislation contained only a few conflict-of-law provisions, which were mainly unilateral. The only bilateral provision was provided in article 707 of the Civil Procedure Code: 'contracts and acts concluded abroad shall be governed by the law of the state within which they are concluded and shall be recognized as valid unless they contradict the public order and are prohibited by the laws of the Empire'. ${ }^{16}$ Some concepts of the general part of PIL, such as a public order or mandatory rules were familiar to the imperial legislation. This provision was inherited by the first Soviet Civil Procedure Code but with more limited wording such as lex loci actus (contractus) shall be taken into

7 Civil Code of the Russian Federation. Third Part of 26.11.2001 (2016) link 10.

8 Civil Code of the Republic of Tajikistan. Part III of 01.03.2005 (2016) link 11.

9 Act of Azerbaijani Republic on Private International Law of 06.06.2000. Azeri text (2016)

link 12; Russian text (2016) link 13.

10 Act of Ukraine on Private International Law of 23.06.2005. Ukrainian text (2016) link 14; Russian text (2016) link 15.

11 Civil Code of the Republic of Moldova of 06.06.2002. English text (2011) link 16; Russian text (2016) link 17.

12 Osoyanu (2010) 3-8.

13 Georgia left the CIS on 18 August 2009.

14 Law of Georgia on Private International Law of 29.04.1998 (2016) link 18.

15 Huo (2011) 1070.

16 Yablochkov (2009) 114. 
account ${ }^{17}$ Interestingly, the choice of law was considered a matter of civil procedure, in contrast to the modern approach.

The October Revolution caused a long stagnation in the development of PIL as well as private law as a whole. As Lenin wrote,

[N]ew civil legislation is being prepared. NKYust ${ }^{18}$ swims with the stream, I see it. But it must fight against the stream. Not to adopt (rather, not to be tricked by stupid old bourgeois lawyers who adopt) the old-line bourgeois concept of civil law, but to create a new one. Not to surrender to Narkomindel, ${ }^{19}$ which "ex officio" insists on the line of "adaptation to Europe", but to fight against this line and elaborate a new civil law, a new approach to "private" contracts, etc. We do not recognize anything "private", for us everything in the area of economy is a matter of public law, not private. We allow state capitalism only, and this is we who are the state, as has been said (...) Hence, to extend the state interference with "private legal" relations; to extend the right of the state to nullify "private" contracts; to apply not the corpus juris romani but our revolutionary legal consciousness to the "civil legal relations". ${ }^{20}$

The idea was embraced by academic circles, and 'a choice-of-law provision inherently is a form varnishing either a capitulation of one state to another at a narrow front, or a onesided solution of an issue on own or alien law application by this state with the aim of serving interests of the dominant class. The agreement on the conventional tariffs after the customs war means not the end of the struggle, but just some stabilization regarding the defined issues, and acceptance of some consistent choice-of-law rules by the states never means the termination of imperialist powers' struggle, even at this narrow front' ${ }^{21}$

As a result, the Civil Codes of the Union Republics, adopted in 1922, contained no choice-of-law rules. The system minimized applicability of foreign law as well as the very chance of foreign elements' occurrence in legal relationships. For example, article 17 of the RSFSR $^{22}$ Civil Code proclaimed the state monopoly on foreign trade, and article 8 of the Resolution on Enactment of the Civil Code provided the right of People's Commissariats to restrict foreigners' rights to free movement, choice of profession, establishment and acquisition of enterprises and purchasing of realty. Foreign associations and partnerships could exercise their rights of legal entities only after being specifically admitted by the government. ${ }^{23}$ In 1947 the legislation prohibited marriages between Soviet citizens and foreigners. ${ }^{24}$

Scarce contacts with citizens and legal entities of the socialist countries were governed by substantive rules of the international treaties widely known as General Conditions of Deliveries. Nevertheless, the Soviet legislation could not reject choice-of-law rules completely. Each of the Union Republics had its own legislation and their provisions

17 Makarov (2009) 49.

18 Abbreviation for 'Narodnyi Komissariat Yustitsii', People's Comissariat for Justice.

19 Abbreviation for 'Narodnyi Komissariat Inostrannykh Del', People's Commissariat for Foreign Affairs.

${ }^{20}$ Lenin (1922/1967) 398.

${ }^{21}$ Rayevich (1934) 43.

22 Abbreviation for 'Russian Soviet Federal Socialistic Republic'.

${ }^{23}$ Resolution of 11.11.1922 on Enactment of the Civil Code of the RSFSR (2016) link 19.

24 Decree of the Presidium of the USSR Supreme Soviet of 15.02 .1947 (2016) link 20. 
differed in some cases. However, in 1931, the Plenum of the USSR Higher Court passed a resolution that contained provisions on choice of law to be applicable within the USSR, inter se. The resolution provided application of lex loci actus to the validity of transactions, lex rei sitae to actions in rem, lex fori to actions in personam, matrimonial and delict cases, with some subsidiary rules to be used at claimant's will. ${ }^{25}$ However, these interlocal choiceof-law rules did not provide for application of non-Soviet law. There were no rules on general issues such as characterization, renvoi or public order due to minimal differences between the Union Republics' legislations.

The international détente of the 1960s changed the Soviet rhetoric from the plea for the world revolution to recognition of equality and coexistence of the systems. The autarchy policy was significantly revised, which led to reanimation of the PIL ideas. For example, the Fundamentals of Civil Legislation of the USSR and the Union Republics enacted in 1961 presented the first attempt of codification of this area of law - section VIII was meaningfully titled 'Legal capacity of foreign citizens and stateless persons, application of civil law of foreign states and international treaties'. It initially consisted of 8 articles, of which only 3 contained choice-of-law rules: Article 125 - on the form of transaction; article 126 - on obligations ensuing from foreign trade transactions and article 127 - on inheritance. Articles 122 and 123 provided a national regime for foreigners and stateless persons and article 124 stipulated a right of foreign companies to enter into contract with authorized soviet entities without being specifically admitted. Article 129 proclaimed the prevalence of international treaties over Soviet laws while article 128 restricted usage of foreign law whose application would contravene with the fundamentals of the Soviet legislation.

In the 1950s the Institute of State and Law at the USSR Academy of Science prepared a Draft Statute on Private International $\mathrm{Law}^{26}$ that covered choice of law not only for civil, but also for matrimonial and employment relations and even contained rules on international procedure. This was never included in the legislative agenda as Lenin's 'we do not recognize anything private' was still in force.

In 1977, five more articles were included in Section VIII which contained the choiceof-law rules on legal capacity of persons, warranty of authority, limitation of action period, property rights and tort liability. ${ }^{27}$ Nevertheless, even after perestroika, the fundamental goal of the Soviet PIL was formulated as 'legal regulation of the state's numerous international economic, scientific-technical and cultural relationships' ${ }^{28}$ In the eyes of western reviewers, the Soviet PIL was still 'designed to anticipate and avoid conflicts rather than resolve them ex post facto' ${ }^{29}$ The legislation was kept in an underdeveloped state in comparison even to the socialist countries' law, e.g., the Czechoslovakian Act on Private International Law and Procedure (1963) consisted of 70 articles and the Hungarian DecreeLaw of 1979 contained of 75 articles.

In the latter years of the USSR, there was another chance to enact a comprehensive statute on PIL and international civil procedure. A bill ${ }^{30}$ of 67 articles had been developed by the Institute of Legislation and Comparative Jurisprudence. This bill was very advanced,

25 Vlasova (1952) 87.

26 Zvekov \& Marysheva (1997) 132.

27 Decree of Presidium of the USSR Supreme Soviet of 15.02.1947 (2016) link 21.

28 Boguslavskii (1988) 18.

29 Kiralfy (1998) 232.

30 Proyekt zakona SSSR 'O mezhdunarodnom chastnom prave i mezhdunarodnom grazhdanskom protsesse’ (1991) 123-61. 
e.g., it recognized renvoi (both remission and transmission). However, the Supreme Soviet decided to keep the old model of codification and simply adopted a new version of the Fundamentals of Civil Legislation in 1991.

The new Fundamentals consisted of 15 articles and seemed to be slightly more open to foreign rules. For example, among the 'grounds for application of foreign law' article 156 listed not only 'the legislative acts of the USSR and the republics and international treaties of the USSR', but also 'agreements of parties not contradicting to them, and international customs recognized in the USSR'. Article 158 titled 'Restriction of Foreign Law' stated that 'a refusal to apply foreign law cannot be based solely on the differences between the political or economic systems of the relevant foreign state and of the USSR'. Among the innovations of the new Fundamentals, there was article 157 called 'Establishment of the foreign law content'. The named articles together with article 162, which allowed the Government to establish retortions for restrictions of the capacity of individuals and legal entities, exhausted the list of issues of the general part of PIL.

The demise of the USSR uncovered a number of problems related to the Union republics suddenly becoming independent. First, a wide variety of civil relations within the former Union incidentally became foreign and this required a new system of co-operation. The areas of PIL which were affected were jurisdiction, choice of law, judicial assistance and recognition (enforcement) of awards. As a result, the new independent states signed the Minsk Convention on Legal Assistance and Legal Relations on Civil, Matrimonial and Criminal Affairs in 1993. This was supposed to play a similar role to the Bustamante Code in Latin America. It mainly consisted of rules on conflict of jurisdictions and it also contained a number of choice-of-law provisions. However, the Convention contained no rule of the general part of PIL as the national civil codes had remained unchanged since the Soviet era and were mutually consistent.

The Minsk Convention, being drafted in order to regulate relations within the CIS members, could not be applied to the relations connected with the 'far-abroad countries'. The new independent states had no experience in drafting of complex legal instruments like civil codes as during the Soviet period they had merely copied the Union's statutes. This had become a prerequisite for the adoption of the CIS MCC in 1994-1996.

In 1994, the CIS Ministers of Justice and Chairmen of the Supreme Courts, at their meeting in St. Petersburg, decided to consider an adjustment of the economic legislation and, in particular, the Civil Codes. The drafting of the MCC was initiated and organized by the Academic and Advisory Center for Private Law of the CIS countries and also by the Russian Presidential Academic and Practical Center of Private Law, both headed by prof. A.L. Makovskiy. ${ }^{31}$

The process of the Code's drafting was financially supported by the Dutch government and assisted by the Institute of the East European Law and Russian Researches of the Leiden University. ${ }^{32}$ The Third Part of the Code that contains, inter alia, Chapter VII 'Private International Law' was drafted between July and December 1995. A Commission, under the chairmanship of prof. A.S. Dovgert (Ukraine) with representatives from Belarus, Georgia, Kazakhstan, Kyrgyzstan, Russia, Uzbekistan and Mongolia, met seven times in Leiden and the Hague and eventually adopted a unified text on the basis of Russian, Kazakh, Ukrainian and Belorussian projects, which had been evaluated by E. Scoles (Oregon

31 Suleymenov (2012) link 22.

32 Suleymenov (2012) link 22. 
University, USA), S. Reynols (Harvard Law School, USA), and M. Polak (Leyden University, Netherlands). ${ }^{33}$ The Commission made a report on the Seventh Plenary Meeting of the CIS Interparliamentary Assembly on 17 February 1996 and the Third Part of the MCC was adopted as a model law for the member states.

\section{A GENERAL REVIEW OF SECTION VII OF THE MCC}

The Section contains 43 articles - an impressive number when compared to the preceding statutory instruments. It became the first enactment to use the term of 'private international law' and to attempt codification of this area of law. It contained two chapters, which can be defined as a general part and special parts of PIL: chapter 68 'General Provisions' and chapter 69 'Choice-of-Law Rules'. Chapter 69, in turn, included 8 paragraphs: 'Persons', 'Personal non-property rights', 'Transactions, agency, limitation of actions', 'Rights in rem', 'Contractual obligations', 'Non-contractual obligations', 'Intellectual property' and 'Law of inheritance'.

It is the author's opinion that the main drawback of Section VII lies in the codification of the PIL rules within the Civil Code. This leads to the necessity of the special PIL rules development (including rules of the general part) on the questions uncovered by this act, such as matrimonial issues, employment relations, merchant shipping, international civil procedure etc., within separate statutory instruments. In the post-soviet reality, the inconsistencies between particular acts and lacuna are unavoidable. For example, the Russian PIL legislation has been criticized because 'the domestic legislation on PIL is distinguished by a huge number of separate statutes, which leads to overlapping, duplication, unsystematic character, and, in many cases, the existence of inconsistent, uncoordinated wordings', 34

For example, the MCC and the majority of the national Civil Codes allow renvoi only in relation to personal capacity, and not, for example, in relation to matrimonial issues. For example, article 244 of the Kazakhstani Code on Marriage (Matrimony) and Family recognizes divorces between the nationals and foreigners that have been granted abroad in compliance with the relevant foreign legislation. This can only be interpreted as a referral to the substantive law rules. Under this approach, repudiation in the form of talaq, given to a Russian wife by a Kazakh husband in the United Arab Emirates should be recognized in Kazakhstan as a valid divorce, despite being invalid according to the Kazakhstan's substantive provisions and the Emirates' PIL rules prescribing remission. ${ }^{35}$

PIL codification in a comprehensive statute could undoubtedly help to avoid problems of this kind. For example, article 3.2 of Azerbaijan's Act on Private International Law provides that renvoi is applicable either to legal capacity or matrimonial issues.

Another problem with the codification that relates to particular areas of law can be seen in the contradiction between the Russian Civil Code and the Civil Procedure Code rules on lex personalis. The Civil Code defines the personal law of a refugee as the law of the country that granted them asylum while the Civil Procedure Code provides no special rules on refugees and its position on this point is limited to the general rule of lex nationalis.

33 Boguslavskii et al. (2013) 212.

34 Get man-Pavlova \& Yerpyleva (2009) 8.

35 Article 13.2 of the UAE Civil Code states: 'talaq shall be governed by the laws of the state of which the husband is a national at the time of the talaq'. The UAE Civil Code (2011) link 23. 
Consequently, one can enjoy substantive legal capacity while experiencing lack of procedural capacity, and vice versa.

This approach planted the idea that PIL is an area of law that is not limited to a section within the Civil Code and should not only contain rules on conflict of laws and conflict of jurisdiction, but also so-called directly applicable substantive law rules. In line with this approach, M.M. Boguslavskii and V.P. Zvekov list thirty, ${ }^{36}$ and sixty-four ${ }^{37}$ respectively, non-exclusive federal legislative instruments [sic], that compose, in their opinion, Russian private international law.

The fundamental values and policies of MCC seem too eclectic. It attempts to be open and flexible and establishes application of the closest connection test and parties' autonomy as its main principles, whilst, on the other hand, the Code provides for all the possible means of exclusion of foreign law. Imperfection of the rationale manifests in a series of contradictions and equivocations, some of which will be discussed below. Also, while being meticulous when it comes to the issues which could be omitted due to their simplicity e.g., application of law of a country with multiple legal systems and reciprocity, the Code ignores some genuinely complex issues that require clear regulation (dépeçage, conflit mobile dans le temps and incidental question).

The legislative technique of the MCC is far from perfect and a number of its rules have been created by the transformation of the old unilateral rules into bilateral without having regard to the context. For example, there was a flawless choice-of-law rule in the 1991 Fundamentals, the civil legal capacity of foreigners and stateless persons in respect of the transactions concluded in the USSR and obligations ensuing from torts committed in the USSR are governed by Soviet law, which was turned into 'Siamese twins' by the MCC. The rule now contains two objects and two connecting factors combined within a single provision - 'civil legal capacity of a natural person in respect of transactions and obligations ensuing from torts are governed by the law of the country of the place of conclusion of transaction or emergence of obligations ensuing from torts.'

The grammar and wording of the MCC and the relevant national Civil Codes are so complicated and cumbersome that some commentators even called for their non-literal interpretation. ${ }^{38}$ 'It appears that uncertainty and ambiguity of wordings, wide usage of reference and blanket rules, constant need for analogy of law application and legal provisions' application being practical impossible without being familiar with their interpretation and explanation given by court rulings are the main distinctive features of the national legislation.' 39

\section{A REVIEW OF PARTICULAR PROVISIONS OF SECTION VII}

The scope of Section VII is revealed in article 1194 titled 'Determination of Law Applicable to Civil Legal Relations Complicated with a Foreign Element'. The article recognizes a party's agreement as a separate ground for determination of the applicable law along with the Code, other statutes, international treaties and recognized international customs in an unprecedented way. This provision could be seen as a permission given to the parties to

36 Boguslavskii (2005) 56-58.

37 Zvekov (2000) 93-95.

38 Tolstykh (2004) 89.

39 Yerpyleva \& Get’man-Pavlova (2008) 78. 
make any law applicable to their relationship of any kind. However, it was apparently an exaggeration that stemmed from a methodological mistake. The principle of lex voluntatis explained by article 1224 provides that 'a contract is governed by the law chosen by a party's agreement unless otherwise provided by law'. Therefore, the parties' agreement shall be seen as an ordinary choice-of-law rule, not as a separate source of PIL equal to the Code or a treaty. Only Kyrgyzstan and Uzbekistan have adopted provisions similar to article 1194 while other member states have recognized lex voluntatis as an ordinary conflict law rule.

Paragraph 3 provides the principle of the closest connection as an all-purpose subsidiary choice-of-law rule: 'if applicable law cannot be determined according to paragraph 1 of this article, the law most closely connected to the civil legal relation complicated with a foreign element shall be applied'. However, the effect of this very advanced idea has been eliminated by enormous enlargement of application of lex fori in some other provisions, as a public order clause.

Paragraph 4 of the article contains a quite obvious provision: 'the application of a foreign law rule can not be limited solely by virtue of the public nature of the rule'. The public nature per se is not sufficient ground for the exclusion of a foreign rule, especially if it is not incompatible with the domestic public order. Lipstein noted that "the question is never whether foreign public law is applicable; it is whether the public law of the forum is applicable in the particular circumstances of the case. [...] However, some of their effects may have to be recognized if they have already occurred abroad. For instance, an act of expropriation abroad, a judgment in rem or a foreign adjudication in bankruptcy may have resulted in a transfer of title; a foreign import or export regulation may render the performance of a contract illegal; a foreign devaluation of currency may affect a debt' ${ }^{40}$

The paragraph can also cover the situations when a legal issue, e.g., limitation of action, is a part of substantive (private) law according to lex fori and a part of procedure (public) law according to lex causae. This rule seems so evident that there is no need for its introduction in the positive law. However, a similar article of the Kazakh Civil Code caused a wide debate demonstrating the legislators' actual 'knowledge' of PIL. It was rejected by the Constitutional Council on the following grounds: 'It follows from the content and meaning of this rule that peremptory application of norms of foreign public law in the territory of the Republic of Kazakhstan is possible [...]. The drafted wording [...] provides for invasion of norms of foreign public law into the public legal matters of Kazakhstan, thereby allowing infringement of sovereignty in the area of public relationships'. ${ }^{41}$

The most obvious and absolutely unnecessary provision is contained in Paragraph 5: 'the rules of the present section on determination of the applicable law by the court are respectively applicable to any other bodies given authority to resolve a question on applicable law'. Apparently, this provision constitutes an attempt of the draftspersons to rectify their own drafting error, which consists in referring to a court instead of simply using the passive voice: the court applies foreign law or the court or another state body applies foreign law instead of foreign law is applied.

Article 1195 'Legal Qualification', in the author's opinion, contains the most complicated wording among all the post-soviet positive law provisions. Despite some

40 Lipstein (1959) 511-12.

41 The Resolution of the Constitutional Council of the Republic of Kazakhstan of 27.03.1998 (2016) link 24. 
reputable statutes such as the EG BGB or the Swiss Federal PIL Act do not deal with this complex issue, the CIS legislators nevertheless have attempted to explain the mechanism of qualification in PIL. However, that has been done not in the best possible way: 'legal qualification of legal notions by a court shall be based on their interpretation in accordance with the law of the country of the court unless otherwise provided by the law. If the legal notions are unknown to the law of the country of the court or known under another name or with another content, and cannot be determined by interpretation in accordance with the law of the country of the court, the law of foreign state can also be applied in their legal qualification'.

The provision has numerous disadvantages. The first is that the object of qualification is identified as a 'legal notion'. ${ }^{42}$ This is in contradiction to the generally accepted approach in which the object of characterization should be a 'legal relation'; 43 'fact or transaction';44 'legal question or problem arising from the factual situation or from some elements of that situation', 45 'factual situation', 'connection factor' and 'foreign law rule',46 'cause of action' and 'rule of law'; ${ }^{47}$ while legal notion can only be an object of interpretation through which the qualification should be accomplished.

Secondly, the article does not specify the type of qualification in question. However, qualification has to be performed in different ways depending on the subject - mainly using lex fori in respect of the cause of action, primarily using lex causae concerning rule of law, and using lex fori only when it comes to the connection factor, with the exceptions made to the principle of lex nationalis and cases of renvoi. Armenia, Belarus, Moldova, Russia and Ukraine have amended the similar provisions of their national legal instruments with wording 'while determining the applicable law', which seems insufficient in comparison to the Spanish, ${ }^{48} \mathrm{Cuban}^{49}$ or Tunisian ${ }^{50}$ rules that directly describe their goal as determination of the applicable choice-of-law rules.

According to the article in question, qualification lege causae is only possible if the legal notion cannot be determined by interpretation in accordance with the law of the country of the court' due to the fact that it is 'unknown to the law of the country of the court or known under another name or with another content'. The draftspersons of the MCC have tried to escape a trap which they have created themselves, having determined a legal notion as an object for qualification. How can a notion be indeterminable under lex fori, if although 'under another name or with another content', the notion is familiar to it? How can a legal notion be known by another name while this legal notion is a name for legal concept itself? As a result, the article's ambiguity makes qualification lege causae impossible, especially by the post-soviet lawyers who usually are not inclined to apply foreign law.

42 In Russian - 'yuridicheskoye ponyatiye', which also can be translated as 'legal term', 'definition', 'concept' - a wording for some legal institute.

${ }_{43}$ Bartin (1897) 225.

${ }^{44}$ Issad (1989) 100.

45 Falconbridge (1952) 106.

46 Lorenzen (1941) 743-44.

${ }^{47}$ North \& Fawcett (1999) 37-39.

48 Article 12.1 of Civil Code of Spain of 24.07 .1889 (2016) link 25.

49 Article 18 of Civil Code of Cuba of 16.07 .1987 (2016) link 26.

50 Article 27 of Code of Private International Law of the Tunisian Republic of 27.11.1998 (2016) link 27. 
The Moldovan Civil Code has abolished even this fleeting possibility of qualification lege causae, when amended the rule in the following way: ' $[. .$.$] the law of a foreign country$ may be applied for their legal qualification, unless civil rights are thus limited or civil liability measures are thus established'. This provision ignores the very aim of the qualification that is application of the proper law which can establish the differing nature and extent of rights and liabilities. The limitation of rights and establishment of liabilities have thus made a precondition of qualification while they should be its result. Such a 'result-oriented' approach has been fiercely criticized by some authoritative scholars, e.g., Kegel, who noted that choice of law should be made 'without reference to substantive rules, with bandaged eyes, 'blind' on the basis of conflict rules'. ${ }^{51}$ The Azerbaijani and Georgian statutes on PIL, on the contrary, do not include any provisions on qualification.

Article 1196 titled 'Establishment of Content of Foreign Law Rules' states that proof of foreign law is generally an obligation of the court and that parties can assist the court in this. The Russian and Armenian Civil Codes were amended with provisions that the court may place the burden of proof on the parties involved in commercial disputes. The Moldovan Code provides the same for all types of cases. Nevertheless, this provision that compels courts to refer to Ministries of Justice, other bodies and experts, could have been considered a matter of procedure rather than a choice-of-law issue and be placed into the Civil Procedure Code.

Some objections might be raised against paragraph 4 providing for application of lex fori 'if despite the measures taken in accordance to the present article, the content of foreign law rules is not established in reasonable time'. This neutralizes the effect of the principle of the closest connection, which states that the preference should be given to the 'subsidiary applicable law' prescribed in a number of cases but not directly to the law of the forum. For example, according to article 1225, the law applicable to a contract is, as a general rule, lex voluntatis, while the primary subsidiary law is lex venditoris and the secondary subsidiary law is the law of the country of the closest connection. However, if neither the court nor the litigant could establish the content of the lex voluntatis rule, according to paragraph 4 the subject matter will be governed not by lex venditoris or the most closely connected law (as provided by article 1225) but directly by lex fori.

Article 1197, cumbersomely titled 'Referral Back or Referral to the Third Country's Law', permits both types of renvoi only in respect of some issues of natural persons' legal capacity. The article contains an interesting mistake - it accepts renvoi, inter alia, 'when the foreign law is applicable under article 1204, paragraphs 1, 3 and 5 of article 1205 and articles 1207 and 1210'. Further, paragraph 5 of article 1205 states that 'recognition of the natural person as incapacitated or partially capacitated is governed by the law of the country of the court'. Therefore, it refers directly to lex fori and any remission or transmission is impossible. Nevertheless, this mistake was mechanically copied into the Civil Codes of Belorussia (articles 1096 and 1104.5), Kazakhstan (1087 and 1905.5), Kyrgyzstan (1170 and 1178.5) and Uzbekistan (1161 and 1169.5).

The Russian and Ukrainian statutes avoided this mistake by providing remission, respectively, 'in cases (...) related to determination of the legal status of a natural person' and 'in cases concerning personal and matrimonial status of a natural person'. The adoption of the remission to the lex fori without adoption of the transmission seems to be just a 
'pillow for brain' ${ }^{52}$ rather than an attempt to provide a choice of proper law. A better rule is contained in the Azerbaijani statute as it allows both types of renvoi in relation to personal legal capacity, matrimonial and inheritance relations. The Armenian and Moldovan Codes provide no renvoi, while the Georgian statute permits both a remission and a transmission in any circumstances, including further transmissions.

The MCC contains all three possible rules for exclusion of the applicable law: evasion of law, application of mandatory rules, public order reservation. They are so incompatible that 'a question may arise, whether the developers of the Section aimed at limitation of the basis for foreign law application and whether they deliberately allowed a list of the so-called 'restriction provisions', which exclude application of foreign law, to lengthen'. ${ }^{3}$ In the academic community, mandatory rules are considered to be a type of public order rules (positive public order) and in the light of post-soviet prejudice against foreign law, the coexistence of positive and negative public order rule within a single statute can make application of foreign law almost impossible.

Article 1198 on 'Consequences of Law Evasion' states that 'agreements and other actions of participants of relations regulated by the Code directed to, evading rules of this Section on applicable law, bringing relevant relations under another law, are invalid. In this case the law of the relevant state applicable under this Section shall be applied'. This wording is per se imperfect as it provides for the rejection of the determined law as a whole, while the actions aimed at evasion are usually conducted in order to prevent application of a particular single provision. Further, this blatantly contradicts article 1094 mentioned above, according to which the agreement of parties is recognized as a separate ground for choice of law. The evasion of law provision was reasonably criticized in the academic circles $^{54}$ and was subsequently rejected by Armenia, Russia, Tajikistan, Moldova and Georgia. However, it was adopted by the Civil Codes of Belarus (1097), Kazakhstan (1088), Kyrgyzstan (1171), Uzbekistan (1162) and Statute of Azerbaijan (8). Also, the Belorussian wording is even less appropriate, as it uses an expression 'evasion of the act of legislation', whereas an evaded rule of foreign law can often be found in a precedent or custom.

Article 1200 on public order clause reservation limits the principle of the closest connection in the same way as article 1196: 'foreign law shall not be applicable when its application would be in contradiction to the fundamentals of law (public order) of [country name]. In such cases the law of [country name] shall be applied'. The rule provides for the direct application of lex fori and ignores 'subsidiary applicable law'. Only the Ukrainian Statute took this problem into consideration, providing that in such cases the law most closely connected to the legal relations is applicable, and if such law cannot be determined or applied, the law of Ukraine shall be applied'.

This rule also restricts application of foreign law as a whole, even in situations when only one of its provisions contradicts the public order. Such an effect was precluded by the statutory instruments of Armenia, Russia, Ukraine, Georgia and Azerbaijan, providing the possibility of a particular foreign law provision being inapplicable. The Azerbaijani rule is also of great interest determining not a public order as an obstacle for foreign law application, but 'Constitution and statutes enacted by referendum'.

52 Yerpyleva \& Get'man-Pavlova (2008) 81.

53 Zvekov (2000) 85.

54 See, e.g. Muranov (1999), Muranov (2011). 
Article 1201 'Application of Imperative Norms' states the following: 'the rules of the present Section do not affect the effect of the imperative norms of the law of [country name] which govern relevant relations irrespective of the law to be applied'. It can sometimes be unclear, which norms of lex fori govern relations in such a manner. The Russian and Kazakh Civil Codes specified them as norms 'which, due to indication in the very norm or to special significance for protection of the rights and legally protected interests of civil relations participants, govern relevant relations irrespective of the law to be applied'. However, the rule caused criticism even in this formulation - 'practically every imperative norm of law can be declared having special significance'. ${ }^{55}$

Paragraph 2 makes the application of a third country's mandatory rules possible 'when the law of any country is applicable in accordance with the rules of the present Section, a court can apply imperative norms of the law of another country most closely connected to the relation if, under the law of that country, such norms should govern the relevant relations, irrespective of the law to be applied. In such cases, the court shall take into account the purpose and nature of such norms and also the consequences of their application'.

The coexistence of the three rules on exclusion of applicable law described above can cause some adverse effects. The applicable law can be rejected and replaced by different legal systems on the ground of any of them. Imagine an old French widower, who has two minor children, was instigated by his young concubine to settle in England and to make a will in her favor, assuming that he had some movable property in a CIS country. He dies shortly after becoming an English domicile, and the woman and children claim for inheritance in the CIS country as a forum rei sitae. According to the MCC, each of the children is eligible for a $1 / 4$ of a given inheritance, ${ }^{56}$ while under French law it is a $1 / 3,{ }^{57}$ and according to English law they can claim only for financial provision in the sum which 'would be reasonable in all the circumstances of the case for the applicant to receive for his maintenance'. ${ }^{58}$ The MCC provision on inheritance provides for application of the English law as the law of the last domicile of the deceased. In this case the three exclusions can cause three different consequences.

If the court provides for the evasion of French law, it will apply the French rules. Also, the court can follow article 1201 and interpret the MCC or the French Civil Code rules as imperative and apply any of them. Finally, the court might declare that the English rule, which provides unclear criteria for the children's claim, contradicts the public order and apply lex fori. However, it also can state that there is no necessity to exclude the English provision.

55 Yerpyleva \& Get'man-Pavlova (2008) 74.

56 Article 1180 of the MCC states the following: 'The minor or disabled children of the testator, and also his disabled spouse and parents shall inherit, irrespective to the content of the will, at least a half of the share each of them is entitled to in the case of succession by law (compulsory share)'. Model Civil Code of the CIS. Third Part of 17.02.1996 (2016) link 1.

57 Article 913 of the French Civil Code declares the following: 'Gratuitous transfers, either by inter vivos acts or by wills, may not exceed half of the property of a disposing person, where he leaves only one child at his death; one-third, where he leaves two children; one-fourth, where he leaves three or a greater number'. Civil Code of the French Republic of 05.03 .1803 (2016) link 28.

58 Article 1.2.b. The United Kingdom Inheritance (Provision for Family and Dependents) Act of 12.11.1975 (2016) link 29. 
Article 1203 keeps the spirit of the Soviet legislation, providing that 'the Government of [country name] may establish reciprocal limitations (retortions) on the rights of citizens and legal entities of the states which have established special limitations on the rights of citizens and legal entities of [country name]'. This article seems to be misplaced because it contains a provision on personal status which could be located in the relevant articles of chapter 69 (as it was done in the Georgian Act on PIL). However, such limitations can be interpreted as mandatory provisions and be enforced on the ground of article 1201. In such a case there would be no need for special provision on retortions in chapter 68 .

This wording was rejected by the Constitutional Council of Kazakhstan on the ground that the limitation of human rights provided by legislation does not fall under the jurisdiction of the government as a body of the executive power. ${ }^{59}$ Consequently, the wording was changed to 'The Republic of Kazakhstan may establish retortions [...]'. The same wording is accepted in the Armenian CC.

Article 1189 is an illustrative example for overregulation, as it contains a rule which could be rejected without any harm done to the law. The article states the following: 'a court or $[\ldots]^{60}$ apply foreign similar relations, unless the application of the foreign law on the reciprocal basis is required by the law of [country name]'. This is merely a remnant of the Cold War when the reciprocity was a condition sine qua law irrespective of whether the law of [country name] is applicable in the relevant foreign state to the non for the application of foreign law. It is the author's opinion that the ad hoc nature of the reciprocity application is enough to consider this article being irrelevant as default. The provision was rejected in the statutes of Azerbaijan and Georgia.

Paragraph 2 seems to be more useful, as it sets the presumption of reciprocity for certain cases: 'if application of a foreign law depends on reciprocity such reciprocity shall be deemed existent unless proven to the contrary'. Nevertheless, this provision practically stays jus nullius, because no conflict rule of Chapter 69 requires reciprocity. The presumption of reciprocity in some sense contradicts the principle of competitiveness, It directly favors the party whose claim is grounded on the existence of reciprocity, putting on the other party the burden of proof of its absence.

Article 1202 titled 'Application of Law of a Country with Multiple Legal Systems' contains another obvious provision: "when the law of a country which has several territorial or other legal systems is to be applied, the applicable legal system shall be determined in compliance with the law of that country'. Considering that some countries have no rules on interlocal or interpersonal conflicts, the legislation of Armenia, Russia, Ukraine, Azerbaijan, Moldova and Georgia included the rule in the following form: 'if under the law of that country it is impossible to define which legal system is applicable, the legal system to which the relation is most closely connected shall be applied'. This amendment is nothing more than an individual case of the general principle of the closest connection and, therefore, its inclusion seems to lead to the overspecification.

Perhaps, the MCC draftspersons aimed to provide the maximum certainty and consistency of the regulation when creating these rules. It must be admitted that the MCC has failed to meet the contemporary needs as it ignored such complex issues of PIL like dépeçage, mobile conflict, incidental (preliminary) question and application of non-state law that require regulation far more than reciprocity or interlocal conflicts. The main reason for concern is that these issues still remain ungoverned in the CIS countries.

59 The Resolution of the Constitutional Council of the Republic of Kazakhstan of 27.03.1998 (2016) link 24.

60 Brackets in original. 


\section{SOME ASPECTS OF THE MCC RULES ADOPTION INTO THE NATIONAL LEGISLATIONS}

The MCC affected the CIS countries' national legislation in different ways but there is an interesting common pattern. The MCC has been substantially welcomed by all pro-Russian countries, Russia's partners within the Eurasian Union and the Organization of Collective Security, such as Armenia, Belarus, Kazakhstan, Kyrgyzstan and Tajikistan. On the contrary, Western-oriented Georgia, Azerbaijan and Ukraine rejected the MCC as a sample for codification and preferred to enact specific statutes, though the latter two have adopted some of its provisions. This has not been gone unnoticed in the academic world: "in the former Soviet Union the method of inter-area codification of PIL has been preferred by the states which mostly kept a socialist sense of justice and adhered to the traditions of Soviet law (as commonly known, not recognizing anything private): Belarus, Kazakhstan, Uzbekistan. The countries whose economic systems are generally focused on the development of private property, competition and cooperation with the industrially developed states have preferred the path of autonomous codification: Georgia, Estonia, Ukraine'. 61

It is hard to say whether the rejection of the MCC was advantageous for these states. For example, the Georgian Statute was based on the EG BGB. Its concise and flexible Chapter I (on general provisions) consists of only 7 articles and does not contain rules on characterization, evasion of law, reciprocity and retortions. This may seem to be an advantage whilst considering the defects of the similar MCC rules, but Georgia has no academic foundations or judicial practice that would be comparable to the German ones and could neutralize the absence of statutory rules. However, the Georgian and the Ukrainian Statutes have the following advantage in that they contain not only the choice-of-law rules but also the provisions on international procedure that have prevented possible inconsistencies.

The Ukrainian Statute has been influenced by the MCC to a certain extent and this influence can be seen in the sequence of the articles' numbering. However, the Ukranian Statute has managed to avoid most of the mistakes. For example, it provides for a 'strong' principle of the closest connection, under which the law determined by a choice-of-law rule cannot be applied, if not connected to the subject matter or if a foreign rule contradicts public order, a court cannot automatically apply lex fori, but should look for another closely connected rule. This statute seems to be the most developed of all the similar legal instruments in the CIS, being the only statute to provide the definitions of basic concepts of PIL. It is pervaded with the idea of legal certainty, which can have an adverse effect on flexibility in some cases, but is absolutely justifiable as a general approach, at least while academics and practice are at the initial stage of their development.

Azerbaijan has not included any provisions on procedure into the PIL Act, but at least managed to avoid inapplicability of the basic choice-of-law principles to the matters exposed by the Civil Code. Azerbaijani legislators managed to avoid some disadvantages of the MCC, but made their own mistakes. For example, there is a clear misunderstanding of the basic concepts in article 7 of the Statute: 'A competent body of the Azerbaijani Republic executive power can impose identical restrictions on citizens and legal entities of the states that apply retortions to citizens and legal entities of the Azerbaijani Republic'.

61 Yerpyleva \& Get’man-Pavlova (2008) 91. 
The legislators did not take into account that a retortion means a countermeasure but not a primary restriction.

Among the states that adopted the MCC, Armenia was the one that has made noticeable amendments to the text, such as rejecting the evasion of a law provision. But not all of those amendments were advanced: some were driven by the desire to simplify the procedure, such as rejections of renvoi and third country's mandatory provisions. The same can be noted about the Moldovan Code.

Russia postponed the enactment of the Third Part of the Civil Code until 2001 and then further amended it in 2006 and 2013, which allowed this country to avoid a number of the shortcomings. For example, it rejected an evasion of a law provision and consideration of parties' autonomy as a separate ground for choice of law. The Russian Civil Code has specified the purpose of characterization ('when applicable law is being determined') and the method of application of law of a state with multiple legal systems. It has widened application of renvoi to all the matters of legal capacity without quoting particular articles, and significantly limited the provisions on exclusion of foreign law. Some of these achievements were also adopted by Tajikistan, which based its Code of 2005 on the initial version of the Russian Civil Code.

The approaches to codification of PIL adopted by Belarus, Kazakhstan, Kyrgyzstan and Uzbekistan, perhaps, could be best described as a blind compilation. The most striking example is the problematic provision on renvoi mentioned above. In addition, the legislators did not modify the impersonal term 'a country of the court' (an absolutely justifiable term for the vocabulary of the Model Code). This is capable of causing a misunderstanding, as, for instance, administrative bodies can also apply conflict law rules.

Such copying was partly done without taking other legal instruments or even other parts of the Civil Codes into consideration. For example, Kazakhstan codified the substantive rules on tutorship and guardianship within the matrimonial legislation, but kept the choice-of-law provisions in the Civil Code.

In some cases, these national statutes contain new errors. For example, the Kyrgyz Civil Code rule on renvoi has integrated both remission and transmission into a single cumbersome construction. The relevant provision, article 1170, is titled as 'Back Referral to the Law of a Third Country' with the provision within the article being of the same wording, both in Russian and Kyrgyz languages.

Other problems arose in connection with the translation of the MCC provisions. For example, the original text 'a court shall establish the content of foreign law provisions in compliance with the official interpretation, application practice and academic understanding in the relevant foreign state' was mistranslated into the Kazakh Civil Code in such a form that the phrase 'in the relevant foreign state' relates to academic works only. In this way, the Kazakh wording provides that 'a court shall establish the content of the foreign law provisions in compliance with the academic understanding in the relevant foreign state, official interpretation and application practice'. Thus, this article can be interpreted in such a way that the Kazakh bodies should follow foreign academic findings and then provide their own official interpretation for foreign rules and establish their own application practice. The situation gets rather absurd as both the Kazakh and Russian texts can be officially used in litigation.

The main problem with these countries' Codes is that they have stayed unchanged since the date of acceptance despite having obvious flaws. Even these codes seem to be more efficient than the Turkmen Civil Code, which does not contain any provisions on PIL at all. Even though some elementary conflict law rules can be found in the Matrimonial 
Code and the Code on Merchant Shipping, no general provisions were adopted. The Law on International Commercial Arbitration contains only one article on choice of law providing application of lex voluntatis and subsidiary rule ('the law defined in accordance with the choice-of-law rules which are considered applicable by arbitration'). The provision of the Law on External Economic Activity is also quite obscure: 'if a contract does not provide regulations on the order of dispute settlement, the applicable law and the place of case consideration are defined according to the universally recognized rules of international law'. Such a lack of conflict law rules in the $21^{\text {st }}$ century is an unprecedented situation but is quite understandable in the light of Turkmenistan's autarchy.

\section{CONCLUSION}

The CIS MCC has played an historical role and, unfortunately, it has had a negative rather than positive impact on the national legislations. It has created a number of problems that could be avoided at the very beginning of the codification process and, as a result, legislators, academics and practitioners now have to waste their time and efforts dealing with unnecessary issues. The Code has helped to direct the development of PIL in the majority of the CIS countries but is it the right direction? Georgia, Ukraine and Azerbaijan have all rejected the MCC for political reasons but have managed to develop more efficient statutes.

The analysis of the national PIL statutes development leads to the conclusion that the discrepancies will increase in the future. It is commonly accepted that the drafting of model statutory instruments within the CIS was not efficient. ${ }^{62}$ Georgia and Ukraine will never join the pro-Russian camp. Azerbaijan can adopt the Turkish model of legislation due to linguistic and cultural ties. Moldova can follow the Romanian example. Even Kazakhstan, one of the Russia's most faithful allies, may change the direction of PIL development. It enacted the Constitutional Statute (on the 'Astana' International Financial Center) that provides a separate jurisdiction based on the legal principles of England and Wales. ${ }^{63}$ It is expected that the common law approach, once partly adopted, can have an impact on the legislation as a whole.

Russia gradually develops its legislation and there is every likelihood that it will eventually enact a comprehensive statute on PIL. The last trends of the academic world seem to suggest this prospect being not improbable. ${ }^{64}$ Some authors offer to make a tradeoff and keep the existing choice-of-law rules in the specific statutes whilst drafting a separate statute that would comprise, at least, the provisions of the general part of PIL. ${ }^{65}$ The Russian legislators have attempted to draft such statutes twice, and, as an old Russian saying states, God loves trinity.

It is difficult to predict anything for the other states. The mere existence of serious inconsistencies and even logical and grammar errors in the PIL legislation show the lack of interest in its development. Probably, these countries will continue to follow the lead of

62 'Besides Model Civil Code the CIS IPA has developed more than 100 model statutes. Obviously, it is not the case when the quantity turns into quality.' Boguslavskii et al. (2013), 85.

${ }_{63}$ Constitutional Act of the Republic of Kazakhstan of 07.12.2015 (2016) link 30.

${ }^{64}$ See e.g. Lebedev et al. (2002); Zvekov (1999); Marysheva (2004).

65 'The special statute on PIL should scope on its general institutes - the problems of qualification, renvoi, public order clause, evasion of law, establishment of content of foreign law, etc.' Yerpyleva (2005) 33. See also Dmitrieva (2010) 78-79. 
Russia but the independent development of PIL seems to be a better option for them. The quicker the states reject the Big Brother's approach, the quicker they establish the own methodology based on their own social and economic values and policies that will allow them to develop the body of rules appropriate for successful integration into the world community.

\section{LITERATURE}

Bartin, É., 'De l'impossibilité d'arriver á la solution définitive des conflits de lois' (1897) 24 Journal du Droit international privé et de la jurisprudence française 225-55, 466-95 and 720-38.

Boguslavskii, M., Private International Law: The Soviet Approach (Winter, D. tr, Martinus Nijhoff 1988).

Boguslavskii, M., Lisitsyn-Svetlanov, A., Trunk, A. (eds), Sovremennoye mezhdunarodnoye chastnoye pravo v Rossii i Yevrosoyuze: Monografiya. Kniga 1 (Modern Private International Law in Russia and the European Union. Monography. Book 1) (Norma 2013).

Dmitrieva, G. (ed), Mezhdunarodnoye chastnoye pravo: uchebnik (Private International Law: Textbook) (Prospekt 2010).

Falconbridge, J.D., 'Conflict Rule and Characterization of Question' (1952) 30/2 The Canadian Bar Review 106-18.

Get'man-Pavlova, I. \& Yerpyleva, N., 'Rossiyskoye zakonodatel'stvo po mezhdunarodnomu chastnomu pravu: problemy sovershenstvovaniya' (The Russian Legislation on Private International Law: The Problems of Perfection) (2009) 1 Mezhdunarodnoye publichnoye i chastnoye pravo $8-14$.

Huo, Zh., 'An Imperfect Improvement: The New Conflict of Laws Act of the People's Republic of China' (2011) 60/4 International and Comparative Law Quarterly 1065-93.

Issad, M., Mezhdunarodnoye chastnoye pravo (Private International Law) (Progress 1989).

Kegel, G., 'Paternal Home and Dream Home: Traditional Conflict of Laws and the American Reformers' (1979) 27/4 The American Journal of Comparative Law 615-33.

Kiralfy, A., 'Review on Private International Law: The Soviet Approach. By Mark M. Boguslavskii' (1998) 38/1 International and Comparative Law Quarterly 232-34.

Lebedev, S., Muranov, A., Khodykin, R., Rabatov, E., 'New Russian Legistation on Private International Law' (2002) 4 Yearbook of Private International Law 117-44.

Lenin, V., 'O zadachakh Narkomyusta v usloviyakh novoy ekonomicheskoy politiki' (On the Tasks of the People's Commissariat for Justice under the New Economic Policy) (1922) in 44 Full Collection of Works (Izdatel'stvo politicheskoy literatury 1967) 398.

Lipstein, K., 'The Hague Conventions on Private International Law, Public Law and Public Policy' (1959) 8/3 The International and Comparative Law Quarterly 506-22.

Lorenzen, E.G., 'Qualification, Classification, or Characterization Problem in the Conflict of Laws' (1941) 50 The Yale Law Journal 743-61.

Makarov, A., Osnovnye nachala mezhdunarodnogo chastnogo prava (The Basic Fundamentals of Private International Law) (Knigodel 2009).

Marysheva, N., 'Voprosy kodifikatsii norm mezhdunarodnogo grazhdanskogo protsessa v Rossii' (The Issues of Codifications of International Civil Procedure Norms) (2004) 6 Zhurnal rossiyskogo prava $35-46$.

Muranov, A., 'VAS idet v obkhod' (The Supreme Arbitral Court Evades) (2011) 77 (2843) Vedomosti 4.

Muranov, A., Problema 'obkhoda zakona'v material' nom i kollizionnom prave (The Problem of Evasion of Law in Substantive and Conflicts' Law) (Candidate of Juridical Sciences thesis MGIMO University 1999).

North, P. \& Fawcett, J., Cheshire and North's Private International Law (13th edn, Butterworth 1999).

Osoyanu, N., Tendentsii $i$ perspektivy razvitiya mezhdunarodnogo chastnogo prava Respubliki Moldova (Trends and Prospects of Development of Private International Law of the Republic of Moldova) (Candidate of Juridical Sciences thesis Kutafin Moscow State Law University 2010). 
Proyekt zakona SSSR 'O mezhdunarodnom chastnom prave i mezhdunarodnom grazhdanskom protsesse' (The USSR Draft Law on Private International Law and International Civil Procedure) (1991) 49 Trudy VNII sovetskogo gosudarstvennogo stroitel'stva i zakonodatel'stva 123-61.

Rayevich S., Mezhdunarodnoye chastnoye pravo (Private International Law) (Sovetskoye zakonodatel'stvo 1934).

Tolstykh, V., Mezhdunarodnoye chastnoye pravo: kollizionnoye regulirovaniye (Private International Law: Conflict Regulation) (Yuridicheskiy tsentr Press 2004).

Vlasova, A. (ed), Grazhdanskiy Kodeks RSFSR. Ofitsialnyi tekst s izmeneniyami na 1 yanvarya 1952 g. is prilozheniyem postateyno-sistematizirovannykh materialov (Civil Code of the RSFSR. The Official Text with amendments on 1 January 1952 and with Article-by-article Systemized Commentaries) (Gosudarstvennoye izdatel'stvo yuridicheskoy literatury 1952).

Yablochkov, T., Trudy po mezhdunarodnomu chastnomu pravu (Works on Private International Law) (Statut 2009).

Yerpyleva, N., Mezhdunarodnoye chastnoye pravo (Private International Law) (Prospekt 2005).

Yerpyleva, N. \& Get'man-Pavlova, I., 'Problemy rossiyskogo zakonodatel'stva po mezhdunarodnomu chastnomu pravu' (The Problems of Russian Legislation on Private International Law) (2008) 1 Advokat 72-91.

Zvekov, V., 'The New Civil Code of the Russian Federation and Private International Law' (1999) 44 McGill Law Journal / Revue de Droit de McGill 525-37.

Zvekov, V., Mezhdunarodnoye chastnoye pravo. Kurs lektsiy (Private International Law. Course of Lectures) (Norma 2000).

Zvekov, V. \& Marysheva, N., 'Razvitiye zakonodatel'stva o mezhdunarodnom chastnom prave' (The Development of Legislature on Private International Law) Zhurnal rossiyskogo prava (1997) 1 129-38.

\section{LINKS}

1. Model'nyi Grazhdanskiy Kodeks dlya gosudarstv-uchastnikov Sodruzhestva Nezavisimykh Gosudarstv. Chast tretya ot 17.02.1996 [Model Civil Code of the Commonwealth of Independent States. Third Part of 17.02.1996] (2015) <www.iacis.ru/upload/iblock/938/018.pdf> accessed 17 December 2016.

2. O'zbekiston Respublikasining Fuqorolik kodeksi. 29.08.1996 Ikkinchi Qism [Civil Code of the Republic of Uzbekistan. Second Part of 29.08.1996] (2016) <www.lex.uz/pages/GetAct. aspx?lact id $=180552>$ accessed 17 December 2016.

3. Grazhdanskiy Kodeks Respubliki Uzbekistan. Chast' Vtoraya ot 29.08.1996 [Civil Code of the Republic of Uzbekistan. Second Part of 29.08.1996] (2016) <www.lex.uz/pages/getact.aspx?lact id=180550> accessed 17 December 2016.

4. Kyrgyz Respublikasynyn Grazhdandyk Kodeksi. 05.01.1998 II Boluk [Civil Code of the Kyrgyz Republic of 05.01.1998] (2016) <http://cbd.minjust.gov.kg/act/view/ru-ru/5/220?cl=ky-kg\& mode=tekst $>$ accessed 17 December 2016.

5. Grazhdanskiy Kodeks Kyrgyzskoy Respubliki. Chast' II ot 05.01.1998 [Civil Code of the Kyrgyz Republic. Part II of 05.01.1998] (2016) <http://cbd.minjust.gov.kg/act/view/ru-ru/5> accessed 17 December 2016.

6. Grazhdanskiy Kodeks Respubliki Armeniya ot 28.07.1998 [Civil Code of the Republic of Armenia of 28.07.1998] (2011) <www.parliament.am/law_docs/050598HO239rus.html?lang= rus\#R12> accessed 17 December 2016.

7. Grazhdanskiy Kodeks Respubliki Belarus` ot 07.12.1998 [Civil Code of the Republic of Belarus of 07.12.1998] (2016) <http://world_of_law.pravo.by/text.asp?RN=HK9800218> accessed 17 December 2016.

8. Qazaqstan Respublikasynyng Azamattyq Kodeksi. 01.07.1999 Yerekshe Bolim [Civil Code of the Republic of Kazakhstan. Special Part of 01.07.1999] (2016) <http://adilet.zan.kz/kaz/docs/ K990000409_> accessed 17 December 2016.

9. Grazhdanskiy Kodeks Respubliki Kazakhstan. Osobennaya Chast' ot 01.07.1999 [Civil Code of the Republic of Kazakhstan] (2016) <http://adilet.zan.kz/rus/docs/K990000409_> (2016) accessed 17 December 2016. 
10. Grazhdanskiy Kodeks Rossiyskoy Federatsii. Chast' Tretya ot 26.11.2001 [Civil Code of the Russian Federation. Part Third of 26.11.2001] (2016) <www.consultant.ru/document/cons_doc_ LAW 34154/> accessed 17 December 2016.

11. Grazhdanskiy Kodeks Respubliki Tajikistan. Chast III ot 01.03.2005 [Civil Code of the Republic of Tajikistan. Part III of 01.03.2005] (2016) <http://mmk.tj/ru/library/grazhdanskii_kodeks_ ch.3.doc $>$ accessed 17 December 2016.

12. Beynəlxalq xüsusi hüquq haqqinda Azərbaycan Respublikasinin 06.06.2000 Qanunu [Act of Azerbaijani Republic on Private International Law of 06.06.2000] (2016) <www.e-qanun.az/ framework/509> accessed 17 December 2016.

13. Zakon Azerbayjanskoy Respubliki o mezhdunarodnom chastnom prave ot 06.06 .2000 [Act of Azerbaijani Republic on Private International Law of 06.06.2000] (2016) <https://pravo.hse.ru/ intprilaw/doc/070801> accessed 17 December 2016.

14. Zakon Ukraini pro mizhnarodne privatno pravo vid 23.06.2005 [Act of Ukraine on Private International Law of 23.06.2005] (2016) <http://zakon3.rada.gov.ua/laws/show/2709-15> accessed 17 December 2016.

15. Zakon Ukrainy o mezhdunarodnom chastnom prave ot 23.06.2005 [Act of Ukraine on Private International Law of 23.06.2005] (2016) <http://kodeksy.com.ua/ka/o_mezhdunarodnom_ chastnom prave.htm> accessed 17 December 2016.

16. Grazhdanskiy Kodeks Respubliki Moldova ot 06.06.2002 [Civil Code of the Republic of Moldova of 06.06.2002] (2016) <http://lex.justice.md/ru/325085/> accessed 17 December 2016.

17. Civil Code of the Republic of Moldova of 06.06.2002 (2011) <www.ebrd.com/downloads/legal/ core/moldova.pdf $>$ accessed 17 December 2016.

18. Law of Georgia on Private International Law of 29.04 .1998 (2016) <https://matsne.gov.ge/ru/ document/download/93712/2/en/pdf> accessed 17 December 2016.

19. Postanovleniye 'O vvedenii v deystviye Grazhdanskogo Kodeksa RSFSR' ot 11.11.1922 g. [Resolution of 11.11.1922 on Enactment of the Civil Code of the RSFSR] (2016) <www.libussr. ru/doc_ussr/ussr_1435.htm> accessed 17 December 2016.

20. Ukaz Prezidiuma Verkhovnogo Soveta SSSR ot 15.02.1947 'O vospreschenii brakov mezhdu grazhdanami SSSR i inostrantsami' [Decree of the Presidium of the USSR Supreme Soviet On Prohibition of Marriages Between the Citizens of the USSR and Foreigners of 15.02.1947] (2016) <www.consultant.ru/cons/cgi/online.cgi?req=doc;base=ESU;n=20128\#0> accessed 17 December 2016.

21. Ukaz Prezidiuma Verkhovnogo Soveta SSSR ot 16.05 .1977 'O vnesenii izmeneniy i dopolneniy v Osnovy grazhdanskogo zakonodatel'stva Soyuza SSR i soyuznykh respublik i v Osnovy grazhdanskogo sudoproizvodstva Soyuza SSR i soyuznykh respublik' [Decree of the Presidium of the RSFSR Supreme Soviet of 16.05.1977 On Amendments of the Fundamentals of Civil Legislation of the USSR and the Union Republics and the Fundamentals of Civil Procedure of the USSR and the Union Republics Civil Prohibition of Marriages Between the Citizens of the USSR and Foreigners] (2016) <www.jurbase.ru/texts/sector175/tez75268.htm> accessed 17 December 2016.

22. Suleymenov, M. 'Kak sozdavalsya Grazhdanskiy Kodeks Respubliki Kazakhstan' [How the Civil Code of the Republic of Kazakhstan Was Created] (2012) <www.zakon.kz/4468365-kaksozdavalsja-grazhdanskijj-kodeks.html> accessed 17 December 2016.

23. The UAE Civil Code (as amended by 1987) (2011) <https://lexemiratidotnet.files.wordpress. com/2011/07/uae-civil-code-_english-translation_.pdf $>$ accessed 17 December 2016.

24. Postanovleniye Konstitutsionnogo Soveta Respubliki Kazakhstan ot 27.03.1998 Ob obraschenii Prezidenta Respubliki Kazakhstan 'O sootvetstvii Konstitutsii Respubliki predstavlennogo na podpis` Grazhdanskogo Kodeksa Respubliki Kazakhstan (osobennaya chast'), prinyatogo Parlamentom Respubliki Kazakhstan 4 fevralya 1998 goda' [The Resolution of the Constitutional Council of the Republic of Kazakhstan of 27.03.1998 On the request of the President of the RK About compliance of submitted for signature Civil Code of the Republic of Kazakhstan (special part), adopted by the Parliament of the Republic of Kazakhstan on February 4 1998, to the Constitution of the Republic] (2016) <http://adilet.zan.kz/rus/docs/S980000001_> accessed 17 December 2016. 
25. Código Civil de España del 24.07.1889 [Civil Code of Spain of 24.07.1889] (2016) <www.boe. es/buscar/act.php?id=BOE-A-1889-4763> accessed 17 December 2016.

26. Código Civil de Cuba del 16.07.1987 [Civil Code of Cuba of 16.07.1987]. (2016) <www.wipo. int/wipolex/en/text.jsp?file id=242552> accessed 17 December 2016.

27. Code de droit international privé de Republique Tunisienne du 27.11.1998 [Code of Private International Law of the Tunisian Republic of 27.11.1998] (2016) <www.jurisitetunisie.com/ tunisie/codes/cdip/cdip1025.htm> accessed 17 December 2016.

28. Code Civil de la République Française du 05.03.1803 [Civil Code of the French Republic of 05.03.1803] (2016) <www.legifrance.gouv.fr/affichCode.do?cidTexte=LEGITEXT00000607072 $1 \&$ dateTexte $=20161217>$ accessed 17 December 2016.

29. The United Kingdom Inheritance (Provision for Family and Dependents) Act of 12.11.1975 (2016) <www.legislation.gov.uk/ukpga/1975/63> accessed 17 December 2016.

30. Konstitutsionnyi zakon Respubliki Kazakhstan ot 07.12.2015 O Mezhdunarodnom finansovom tsentre [Constitutional Act of the Republic of Kazakhstan on 'Astana' International Financial Centre of 07.12.2015] (2016) <http://adilet.zan.kz/rus/docs/Z1500000438> accessed 17 December 2016. 